\title{
An ANP approach for the stakeholder analysis in participatory environmental management. The case of Spanish wetland La Albufera
}

\author{
Pablo Aragonés-Beltrán \\ INGENIO (CSIC-UPV) \\ Universitat Politècnica de València \\ Camino de Vera s/n, \\ 46022 Valencia, Spain. \\ Email: aragones@dpi.upv.es \\ Mónica García-Melón \\ INGENIO (CSIC-UPV) \\ Universitat Politècnica de València \\ Camino de Vera $\mathrm{s} / \mathrm{n}$, \\ 46022 Valencia, Spain. \\ E-mail:mgarciam@dpi.upv.es
}

\begin{abstract}
The aim of this paper is to analyze the influence of the stakeholders in a participatory decision making process. For that, the relationships and influences among stakeholders involved in a specific environmental problem, namely rice straw management in the Natural Park of La Albufera, Valencia (Spain), have been studied using an Analytic Network Process approach.

The main question we set is how to measure the influence among stakeholders. This a complex question in a real life problem, due to the difficulty for a stakeholder to answer the direct question: Who do you think exerts more influence on you when you have to solve a problem?

In this work, we present a case study assuming that the information exchange is the way to measure the influence among the individuals in the network. We will use these data to solve an easy ANP model. This model is a first approach to prove the utility of ANP to measure the influences among stakeholders in a Social Network.
\end{abstract}

Keywords: Analytic Network Process; stakeholder analysis, participatory decision making. 
Aragonés-Beltrán, García-Melón/ An ANP approach for the stakeholder analysis in participatory environmental management. The case of Spanish wetland La Albufera To Be Submitted to the International Symposium of the Analytic Hierarchy Process 2014, Washington D.C., U.S.A.

\section{Introduction}

Due to the complexity and interrelations of the problems caused by global society (economic development, natural resource management, global warming, and so on) public policy managers must conduct a stakeholder analysis to identify and take account of the individuals, groups and organizations involved in or affected by such policies (Bryson, 2004).

The present work analyzes the influences among stakeholders involved in a specific environmental problem, namely rice straw management in the Natural Park of La Albufera, Valencia (Spain). The case study includes different entities identified as being stakeholders over many years. Identifying the stakeholders is not within the scope of our study, but rather analyzing (and quantifying) which stakeholders have more influence on the decision-making process under study.

Our proposal is to use ANP to measure the influences between the stakeholders of this network. This is not an easy task because of the difficulty to directly ask the following question to each stakeholder: Who do you think exerts more influence on you when you have to solve a problem? We have to use indirect questions. In this work, we use the information exchange flow as a way to measure the influence among individuals of the Network. This model is a first approach to prove the utility of ANP to measure the influences between stakeholders in a Social Network.

\section{Literature Review}

Environmental management takes place at many levels (local communities, city, state, ...) and involves a large number of stakeholders (such as landowners, entrepreneurs, urban planners, farmers...) with conflicting interests (Regan et al., 2006). The complexity of environmental problems requires transparent and flexible decision-making processes that integrate different areas of knowledge and values (Reed, 2008). In order to reach a consensus-based solution all stakeholders should get involved in the decision process (García-Melón et al., 2008)

Prell et al. (2009) suggest that the increasing use of stakeholder analysis in natural resources management reflects the recognition that stakeholders can and should influence environmental decision-making processes (Prell et al., 2009).

The participation of stakeholders in environmental management planning and decision making is a real problem that has not been fully resolved, although there are different approaches and techniques which address specific problems (Janssen et al., 2006), (Goosen et al., 2007), (Bars and Grusse, 2008), (Elgin and Weible, 2013), (Ceccato et al., 2011), (O’Toole et al., 2013). 
Aragonés-Beltrán, García-Melón/ An ANP approach for the stakeholder analysis in participatory environmental management. The case of Spanish wetland La Albufera To Be Submitted to the International Symposium of the Analytic Hierarchy Process 2014, Washington D.C., U.S.A.

Several approaches have been proposed to investigate the relationships among stakeholders, like the basic stakeholder analysis technique, power versus interest grids, stakeholder influence diagrams, the participation planning matrix, interrelationship diagrams (Bryson, 2004), or actor-linkage matrices (Biggs and Matsaert, 1999). However, these techniques do not allow determining an individual value of the influence of each actor in a decision-making process.

\section{Hypotheses/Objectives}

The main objective of this work is: to apply ANP to analyze and measure the influences among stakeholders in a Social Network

\section{Research Design/Methodology}

In this research we set an easy ANP model in which 8 individuals of a Social Network are the elements of the network. Because we do not have many stakeholders, we do not have clusters. The problem is focused on the way we can establish the influences between individuals and how to measure these influences.

In a first step, we decided to use the information flow among them, asking the question: Regarding the consequences of the different rice straw management methods, who do you ask for information and how often?.

From these data we obtain the following relationship matrix:

Table 3. Information matrix active search

\begin{tabular}{|c|c|c|c|c|c|c|c|c|}
\hline MATRIX 1 & 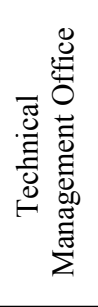 & 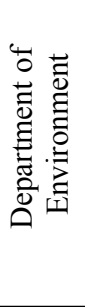 & 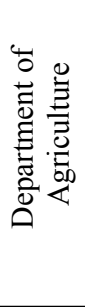 & 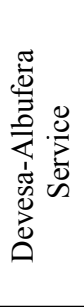 & 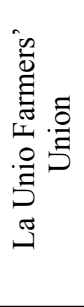 & 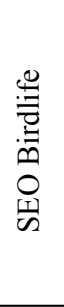 & 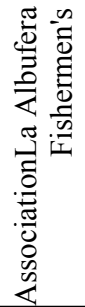 & 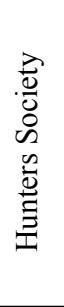 \\
\hline $\begin{array}{l}\text { Technical } \\
\text { Management Office }\end{array}$ & 0 & 1 & 1 & 1 & 1 & 1 & 1 & 0 \\
\hline $\begin{array}{l}\text { Department of } \\
\text { Environment }\end{array}$ & 1 & 0 & 1 & 1 & 1 & 0 & 0 & 0 \\
\hline $\begin{array}{l}\text { Department of } \\
\text { Agriculture }\end{array}$ & 0 & 0 & 0 & 0 & 1 & 0 & 0 & 0 \\
\hline $\begin{array}{l}\text { Valencia City Council } \\
\text { (Devesa- } \\
\text { AlbuferaService) }\end{array}$ & 1 & 0 & 0 & 0 & 1 & 1 & 0 & 0 \\
\hline $\begin{array}{l}\text { La Unio Farmers' } \\
\text { Union }\end{array}$ & 0 & 1 & 1 & 0 & 0 & 1 & 0 & 0 \\
\hline SEO Birdlife & 1 & 1 & 1 & 0 & 1 & 0 & 0 & 0 \\
\hline $\begin{array}{l}\text { La Albufera } \\
\text { Fishermen's }\end{array}$ & 1 & 1 & 0 & 1 & 0 & 1 & 0 & 1 \\
\hline
\end{tabular}

International Symposium of 3

Washington, D. C. the Analytic Hierarchy June 29 - July 2, 2014

Process 
Aragonés-Beltrán, García-Melón/ An ANP approach for the stakeholder analysis in participatory environmental management. The case of Spanish wetland La Albufera To Be Submitted to the International Symposium of the Analytic Hierarchy Process 2014, Washington D.C., U.S.A.

\begin{tabular}{|l|c|c|c|c|c|c|c|c|}
\hline Association & & & & & & & & \\
\hline Hunters Society & 1 & 0 & 0 & 1 & 0 & 0 & 1 & 0 \\
\hline
\end{tabular}

From this matrix, and analyzing the intensity of the flow of information we will fill the pairwise comparison matrix we need to apply ANP. The scale used is: yearly, monthly, weekly. At present we are working on this model to obtain the results and conclusions.

\section{Data/Model Analysis}

From this matrix, and analyzing the flow of information we fill the pairwise comparison matrix we need to apply ANP. At present we are working on this model to obtain the results and conclusions.

\section{Limitations}

The most important limitation is that we have to use indirect questions to measure the influences among stakeholders

\section{Conclusions}

We hope to show the utility of ANP to analyze the influence among stakeholders in a Social Network. In our opinion, this is a new field to use the possibilities of ANP

\section{Key References}

List here only those 3 to 5 references that are key for the study at hand. As an example:

Bryson, J.M., 2004. What to do when stakeholders matter. Public management review 6, $21-53$

Regan, H.M., Colyvan, M., Markovchick-Nocholls, L., 2006. A formal model for consensus and negotiation in environmental management. Journal of Environmental Management 80, 167-176.

Reed, M.S., 2008. Stakeholder participation for environmental management: A literature review. Biological Conservation 141, 2417-2431.

García-Melón, M., Aragonés-Beltrán, P., González-Cruz, M.C., 2008. An AHP-based evaluation procedure for Innovative Educational Projects: A face-to-face vs. computermediated case study. Omega 36, 754-765.

Prell, C., Hubacek, K., Reed, M., 2009. Stakeholder Analysis and Social Network Analysis in Natural Resource Management. Society \& Natural Resources 22, 501-518

\section{Appendices}

